DE DE GRUYTER

OPEN

DOI 10.1515/pesd-2015-0030

PESD, VOL. 9, no. 2, 2015

\title{
FLOOD ANALYSIS USING HYDROLOGICAL MODELING. CASE STUDY - THE FLOOD IN THE UPPER CATCHMENT OF RIVER GERU, GALAȚI COUNTY, ROMANIA
}

\author{
Isabela Balan ${ }^{1}$, Loredana Crenganiș ${ }^{2}$, Claudiu Pricop ${ }^{3}$
}

Key words: hydrological modelling, rainfall, runoff, automatic station, radar

\begin{abstract}
This paper analyzes the flood that occurred between $11^{\text {th }}$ and $13^{\text {th }}$ of September 2013 in the upper catchment of the river Geru. The flood was simulated using the program Mike by DHI with the Unitary Hydrograph Method. As input data, we used the precipitation measured at the Automated Hydrological Sensor Station Cudalbi and radar precipitations. We analyzed the importance of accuracy for input data on the simulation results and the direct influence of setting the proper time steps in achieving the simulated discharge hydrograph. It appears that radar precipitations used as input data lead to a discharge hydrograph with low errors for amplitude and phase of the runoff peak.

The model can be used in the future to reproduce the floods produced in the analyzed catchment and to study the influence of physical and geographical characteristics of the hillslopes.
\end{abstract}

\section{Introduction}

To evaluate surface runoff in small catchments that are homogeneous from the physico-geographical point of view, only the processes of rainfall transformation in runoff are modeled, without the study of flood routing through the riverbeds. In the formation of network discharges during high intensity rainfalls, the most important weight is held by surface runoff (Giurma I., 2003). These types of hydrological models only study the surface runoff component and assume that the parameters used are constant across the entire catchment, so they are models with global parameters. The models evaluate and then integrate the net rainfall. Evaluation of net rainfall is done through a series of mathematical models (Serban, 1989), of

\footnotetext{
${ }^{1}$ Eng. PhD. Stud. "Gheorghe Asachi" Technical University of Iasi, Romania, isabela.balan@yahoo.co.uk

${ }^{2}$ Lect. PhD. "Gheorghe Asachi” Technical University of Iasi, Romania,

${ }^{3}$ Eng. PhD. Water Basinal Administration Prut-Bârlad, Romanian Waters National Administration
} 
which the most widely used model is the model SSAR (Rocwood D., 1981). Integration of net rainfall in surface runoff is performed using a weighted function, called unit hydrograph (Drobot R., Giurma R., 1990).The Unit hydrograph function is the response of the catchment to a $1 \mathrm{~mm}$ net rainfall, uniformly distributed on the surface of the catchment and having the duration $\Delta t$; it is defined by the ordinates:

$$
\mathrm{U} . \mathrm{H} .=\left\{\mathrm{u}_{\mathrm{i}}=\mathrm{u}(\mathrm{i}, \Delta \mathrm{t})\right\} ; \mathrm{i}=1,2, \ldots \ldots, \mathrm{n}_{\mathrm{u}}
$$

where $u_{i}$ is the ordinate of the unit hydrograph at the moment of time $i ; \mathrm{n}_{\mathrm{u}}$ is the number of ordinates taken into account, so that:

$$
\sum_{i=1}^{n_{u}} u_{i} \approx \frac{1}{T}
$$

where $T$ is the number of hours of time step $\Delta t$.

Mathematical modelling of rainfall-runoff process on the hillslopes, resulting in a runoff hydrograph in the closing section of a catchment can be achieved using MIKE by DHI software, which includes in the hydrological module Rainfall Runoff, a unit hydrograph model (UHM). The UHM calculates excess rainfall and determines seepage losses by four methods:

- the method using SCS Curve Number parameter to characterize the analyzed catchment from the perspective of existing soil type and land use patterns.

-the constant loss method that sets an initial fixed value and a constant value during rainfall

- the rational method that describes infiltration as a proportional loss - SCS method which takes into account the Curve Number.

- SCS method generalised

Excess rainfall is routed to the river and transited through unit hydrograph method. The model divides the flood generating precipitation in excess rainfall (net rainfall) and losses (infiltration).

In accordance with the principle of superposition, UHM model determines a flow hydrograph corresponding to each step of computation time and excessive rain, according to the method of calculating the losses and then adds the flow generated in the previous step time. The evolution of the runoff can be described in different ways:

- The triangular hydrograph SCS method (Soil Conservation Service of USDA), which establish that the moment of occurrence of the maximum flow (peak hydrograph) is considered to be at half the duration of the rain, plus the duration between the nucleus of the rain and the peak of the runoff; 
- Reduced SCS hydrograph derived from a number of unit hydrograph with different sizes and locations associated with the catchment.

- User defined hydrograph. The module includes the possibility of establishing dimensionless hydrographs and facilities for setting up and managing databases with runoff hydrographs basins defined a priori by the user and recorded time series of precipitation and discharges.

During rainfall, a part of the total precipitation infiltrates into the soil, than the infiltration is evaporated or routed as base flow to the river bed, a long period after the end of the rainfall. Hence in event models as the present one, it is reasonable to describe the major part of the infiltration as loss. The amount of rain actually reaching the river (the total amount of rainfall less the los) is termed the excess rainfall.

The SCS loss method uses the parameter AMC for defining the antecedent moisture condition at the start of the storm. The model operates with three different antecedent moisture conditions namely:

- $\mathrm{AMC}=1$ Dry conditions close to wilting point.

- $\mathrm{AMC}=2$ Average wet conditions close to field capacity.

- $\mathrm{AMC}=3$ Wet conditions close to saturation.

Another parameter used by SCS loss method is the parameter CN (Curve number), which is a dimensionless coefficient whose value varies between 0 and 100. Setting the value of the parameter $C N$ requires knowledge of certain specific factors basin: soil type, land use, hydrological conditions, antecedent moisture condition and existing impervious surfaces in the catchment.

To create a valid rainfall-runoff model using MIKE 11 software the following files are required:

a) time series file with the extension $* \mathrm{dfs} 0$ containing the precipitations;

b) file with the extension *rrl1 which is the editor of the rainfall-runoff model;

c) file with the extension *sim 11 which performs the hydrological simulation.

To run a hydrological model the following steps are required:

a) In the file *rr11, in the catchment option, the catchment parameters (name, hydrological model and catchment area) are set and then the characteristic parameters of the model are determined.

b) Link the meteorological data (rainfall) from the $* \mathrm{dfs} 0$ extension file as INPUT data in the TIME SERIES option;

c) Create a file with the extension *dfs0 with hydrological data (significant flow hydrographs registered at the hydrometric stations in the analyzed catchment);

d) Create the simulation file *sim11 where the option Rainfall-runoff Model is checked, the file *rr1 1 is uploaded, the simulation period is set, the path and name for the Results are chosen, the simulation is started. 
e) The Results can be viewed in MIKE View.

The model can present the net rainfall and comparison of simulated and measured runoff hydrographs and accumulated volumes for the analyzed flood.

\section{Case study}

1.1. The characteristics of the analyzed catchment

The model is applied to the upper basin of the river Geru located in Galati county, in the south of the area operated by the Basinal Water Administration Prut - Bârlad. The area of the river Geru catchment is $113.56 \mathrm{~km}^{2}$ (river Geru - 99.52



Fig.1. Cartograme of texture soils in the catchment of river Geru

$\mathrm{km}^{2}$ and river Geruşiţa tributary $-14.04 \mathrm{~km}^{2}$ ). The river Geru is a right tributary of the river Suhu. The upper catchment was chosen for study. The downstream control section is Cudalbi hydrometric station, located at $22.53 \mathrm{~km}$ downstream. The confluence of river Gerușiţa with river Geru is located $5.25 \mathrm{~km}$ downstream 
from the spring of the river. The river Geruşiţa is a left tributary, with a length of $7.27 \mathrm{~km}$ and a $14.04 \mathrm{~km}^{2}$ catchment.

The analyzed catchment is controlled by the hydrometric station located in the village Cudalbi. The daily transmitted data from the classic hydrometric station with vertical hydrometric surprise are doubled since August 2013 with hourly precipitation data from the AHSS (Automated Hydrological Sensor Station) established in the DESWAT program, implemented by the Water Basinal Administration Prut - Bârlad.

Cultivated agricultural lands occupied the largest area in the catchment Geru (45\%). As follows meadows (25\%), rural localities $15 \%$, and forests $(15 \%)$.

The catchment of river Geru shows very different soil types: river deposits, carbonate silts, colluvial soils, chernozem soils. Grey forest soils occur on the hillslopes and are formed of loess, sand and marl. Figure 2 presents the textural classes of soils in the catchment of river Geru.

\subsection{Significant flood that occurred in September 2013}

Between $11^{\text {th }}$ and $13^{\text {th }}$ of September in the upper catchment of river Geru large quantities of precipitation occurred. Following the rapid concentration of runoff on the hillslopes, in the reference period, the defense characteristic threshold DANGER was reached and exceeded on river Geru (Table 1):

Tab. 1. Exceedance of DANGER defense threshold at the hydrometric station Cudalbi

\begin{tabular}{|l|c|c|c|c|c|}
\hline River & $\begin{array}{c}\text { Hydrometric } \\
\text { station }\end{array}$ & $\begin{array}{c}\text { Maximum } \\
\text { Level }(\mathbf{c m})\end{array}$ & $\begin{array}{c}\text { Maximum Discharge } \\
\left(\mathbf{m}^{\mathbf{3}} / \mathbf{s}\right)\end{array}$ & $\begin{array}{c}\text { Exceedance of DANGER } \\
\text { defense threshold (cm) } \\
/ \text { date }\end{array}$ & $\begin{array}{c}\text { Maximum Hystoric } \\
\text { Level (cm)/Year }\end{array}$ \\
\hline Geru & Cudalbi & 358 & 118 & $\begin{array}{c}+88 \mathrm{~cm} \\
\text { On } 11^{\text {th }} \text { of September 2013,2300 }\end{array}$ & $358 / 2013$ \\
\hline
\end{tabular}

Rainfall that occurred between $11^{\text {th }}$ and $13^{\text {th }}$ of September 2013 generated a flow hydrograph with three peaks, with the following maximum discharges: 118.00 $\mathrm{m}^{3} / \mathrm{s}$ recorded on $12 / 09 / 201323^{00}$, then $75.30 \mathrm{~m}^{3} / \mathrm{s}$ recorded on $13 / 09 / 201302^{20}$, respectively $10.30 \mathrm{~m}^{3} / \mathrm{s}$ recorded on $13 / 09 / 201310^{00}$. The flow hydrograph was extracted from the rating curve calculated by the Hydrology Department of the Basinal Water Administration Prut - Bârlad for the cross section of the river Geru at Cudalbi hydrometric station.

It appears that the flood that occurred $11^{\text {th }}$ and $13^{\text {th }}$ of September 2013 had a maximum discharge of $118.00 \mathrm{~m}^{3} / \mathrm{s}$ that is very close to the peak of the flood with a $2 \%$ probability of exceedance, which is $120.00 \mathrm{~m}^{3} / \mathrm{s}$, established by the National Institute of Hydrology and Water Management, for the analyzed section. 


\subsection{Mike 11-UHM simulations performed with the use of rainfall recorded} at AHSS Cudalbi

To simulate the flood that occurred between $11^{\text {th }}$ and $13^{\text {th }}$ of September 2013 we used the hydrological model that was built in the project "Hazard and flood risk maps for the river Bârlad catchment". The model included the river Geru and its tributary, the river Geruşiţa and it used the unitary hydrograph method the Rainfall - Runoff Module. The model was calibrated and validated for the flood which occurred in May 2008.

UHM parameters used in the model are shown in Figure 2.

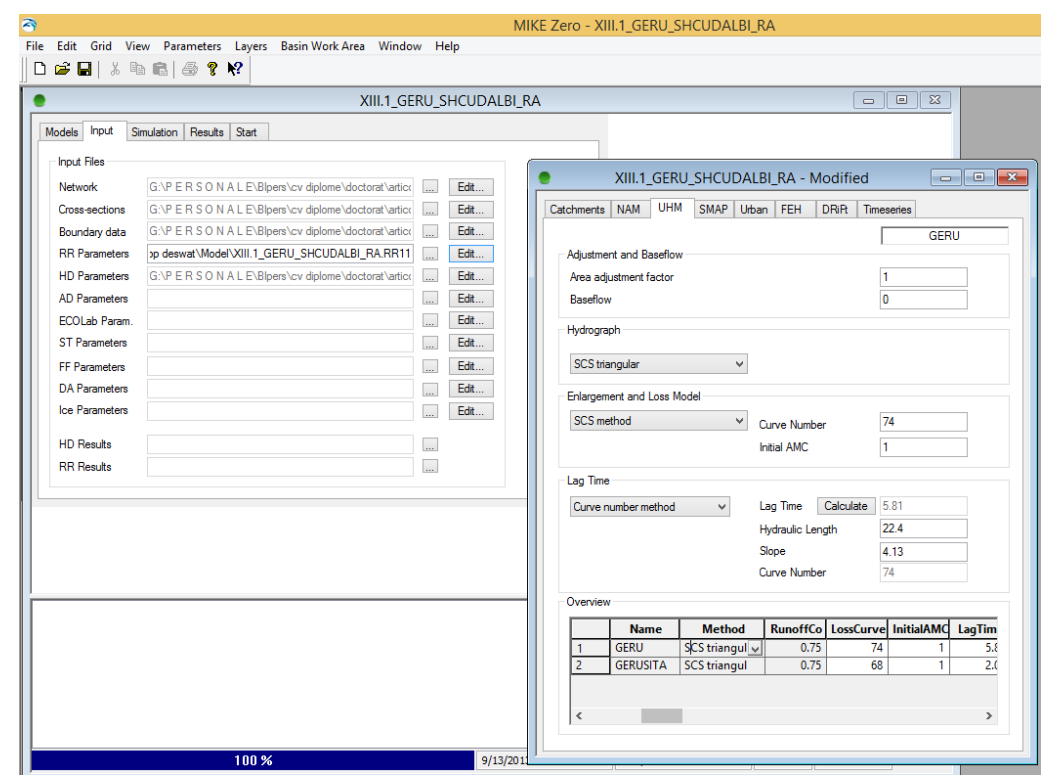

Fig.2. Setting the parameters for the model Mike 11 - Unitary Hydrograph Method

Triangular method was used to draw the hydrograph and SCS method was used to calculate the infiltration.

Mostly clay soil and clay loam, with low infiltration are spread in the river Geru catchment. The soils are classified in the group $C$ of hydrological soils. For the analyzed catchment the $C N$ (Curve Number) parameter was calculated by the weighted method established in TR - 55 (Technical Release - 55) by the United States Department of Agriculture. The method is applicable to small basins and $C N$ parameter is calculated as a weighted average based on land use and $C N$ intermediate surface corresponding to each surface. Table 2 presents the 
calculation of the weighted $C N$ parameter with detail on both the river Geru and the tributary river Geruşiţa catchments.

Tab.2. The calculation of weighted coefficient $\mathrm{CN}$ for the catchments

\begin{tabular}{|c|c|c|c|c|c|c|}
\hline & Area of river Geru catchment $=$ & \multicolumn{2}{|l|}{99.52} & \multirow[b]{2}{*}{$\begin{array}{c}C N \\
\text { partial }\end{array}$} & \multirow[b]{2}{*}{$C N \times$ area } & \multirow[b]{2}{*}{$\mathrm{CN}$} \\
\hline & & $\begin{array}{c}\text { Percentage } \\
\text { of the } \\
\text { catchment }\end{array}$ & $\begin{array}{c}\text { Intermediate } \\
\text { area }-\mathrm{km}^{2}\end{array}$ & & & \\
\hline \multicolumn{2}{|c|}{ Cultivated agricultural lands } & 0.45 & 44.784 & & 3486.88224 & \multirow{10}{*}{77.86} \\
\hline Fallow & Bare soil & 0.01 & 0.44784 & 91 & 40.75344 & \\
\hline \multirow{4}{*}{ Row crops } & Straight row & 0.01 & 0.44784 & 88 & 39.40992 & \\
\hline & Straight row + Crop residue cover & 0.02 & 0.89568 & 85 & 76.1328 & \\
\hline & Contoured \& terraced & 0.10 & 4.4784 & 80 & 358.272 & \\
\hline & $\begin{array}{l}\text { Contoured \& terraced + Crop } \\
\text { residue cover }\end{array}$ & 0.20 & 8.9568 & 77 & 689.6736 & \\
\hline \multirow{3}{*}{ Small grain } & Straight row + Crop residue cover & 0.10 & 4.4784 & 80 & 358.272 & \\
\hline & Contoured \& terraced & 0.05 & 2.2392 & 78 & 174.6576 & \\
\hline & $\begin{array}{l}\text { Contoured \& terraced + Crop } \\
\text { residue cover }\end{array}$ & 0.31 & 13.88304 & 77 & 1068.99408 & \\
\hline $\begin{array}{l}\text { Close-seeded } \\
\text { legumes }\end{array}$ & Contoured \& terraced & 0.20 & 8.9568 & 76 & 680.7168 & \\
\hline \multirow{3}{*}{ Forrest } & & 0.15 & 14.928 & & 992.712 & \multirow{3}{*}{66.50} \\
\hline & Woods & 0.30 & 4.4784 & 70 & 313.488 & \\
\hline & Brush & 0.70 & 10.4496 & 65 & 679.224 & \\
\hline \multirow{4}{*}{ Localities } & & 0.15 & 14.928 & & 1138.26 & \multirow{4}{*}{76.25} \\
\hline & Open space (lawns, parks, etc.) & 0.45 & 6.7176 & 74 & 497.1024 & \\
\hline & Streets and roads - gravel & 0.05 & 0.7464 & 89 & 66.4296 & \\
\hline & Residential districts & 0.50 & 7.464 & 77 & 574.728 & \\
\hline \multirow[t]{3}{*}{ Meadow } & & 0.25 & 24.88 & 71 & 1766.48 & 71.00 \\
\hline & $C N$ for the river Geru catchment $=$ ? & & & & & \\
\hline & Area of river Gerusita catchment & $\overline{14.04}$ & $\mathrm{~km}^{2}$ & & & \\
\hline \multirow{3}{*}{ Forrest } & & 0.75 & 10.53 & & 705.51 & 67.00 \\
\hline & Woods & 0.40 & 4.212 & 70 & 294.84 & \\
\hline & Brush & 0.60 & 6.318 & 65 & 410.67 & \\
\hline Meadow & & 0.20 & 2.808 & 71 & 199.368 & 71.00 \\
\hline \multicolumn{2}{|c|}{ Cultivated agricultural lands } & & & & & \\
\hline Row crops & $\begin{array}{l}\text { Contoured \& terraced + Crop } \\
\text { residue cover }\end{array}$ & 0.05 & 0.702 & 77 & 54.054 & 77.00 \\
\hline
\end{tabular}

For the initial moisture expressed by AMC (Antecedent Moisture Condition) parameter we used in first stage the value 1 specific to dry land, with humidity near the wilting coefficient. The Lag Time parameter (the time interval between the rain nucleus upon reaching maximum flood flow) was calculated automatically by the software by selecting the Curve Number method formula developed by NRCS (Natural Resources Conservation Services, USDA), when provided values for hydraulic length, slope and $C N$. The rainfall recorded by the AHSS Cudalbi with a 10 minutes time step is shown in Figure 3. 
For simulation time step it was chosen the time step of 10 minutes, to coincide with rainfall recording accuracy. For the parameter $A M C$ it was used the value 1 and for the parameter area adjustment factor it was also used the value 1.The comparison between the hydrograph of the discharges measured at AHSS Cudalbi between $11^{\text {th }}$ and $13^{\text {th }}$ of September 2013 and the hydrograph of discharges simulated with Mike Unitary Hydrograph Method is presented in figure 4.

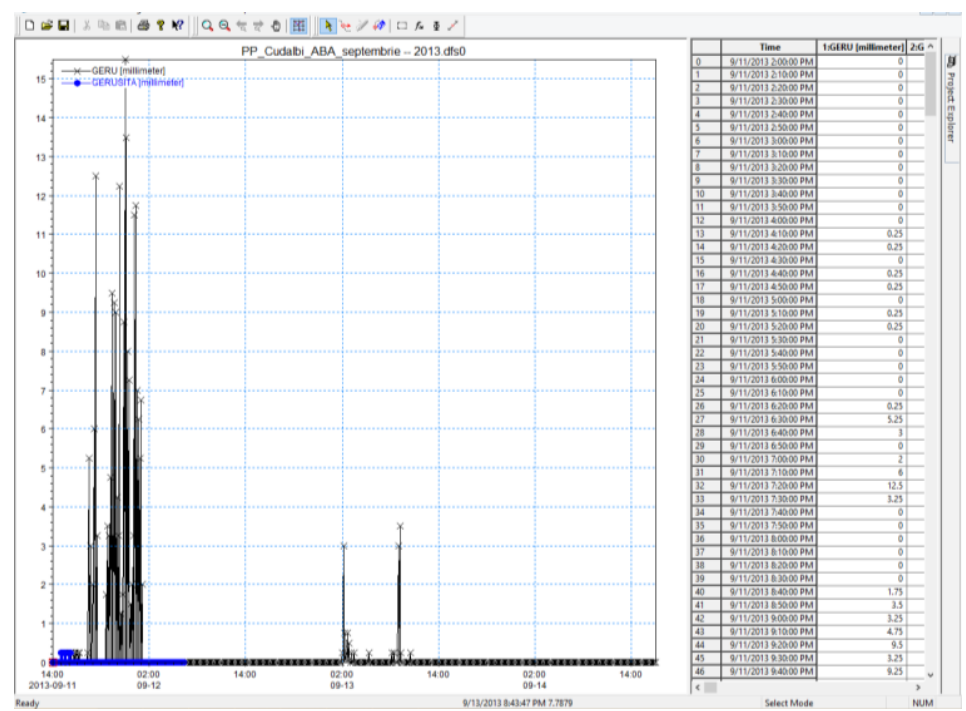

Fig. 3. Precipitation recorded AHSS Cudalbi between $11^{\text {th }}$ and $14^{\text {th }}$ of September 2013

It is found that the maximum simulated discharge was $242.85 \mathrm{~m}^{3} / \mathrm{s}$ (on $12^{\text {th }}$ of September $201306^{00}$ ), compared to the maximum measured discharge of 118.00 $\mathrm{m}^{3} / \mathrm{s}$ (on $11^{\text {th }}$ of September $201323^{00}$ ), so the peak value is increased by $105 \%$ and appears to show 7 hours later than the measured peak.

The simulated hydrograph does not capture the other 2 peaks recorded on $13^{\text {th }}$ of September 2013, which means that there is a difference between the intensity of the rainfall produced in the catchment and the rainfall records from AHSS Cudalbi.

When using the value 0.71 for the parameter area adjustment factor in the setup menu for the parameters used for the simulation, it is found that the maximum simulated discharge is $120.10 \mathrm{~m}^{3} / \mathrm{s}\left(12^{\text {th }}\right.$ of September $\left.201306^{00}\right)$ compared to the maximum measured discharge of $118.00 \mathrm{~m}^{3} / \mathrm{s}\left(11^{\text {th }}\right.$ of September $201323^{00}$ ), so the peak value is increased by $1.8 \%$ and appears to show 7 hours later than the measured peak. (Figure 5). 


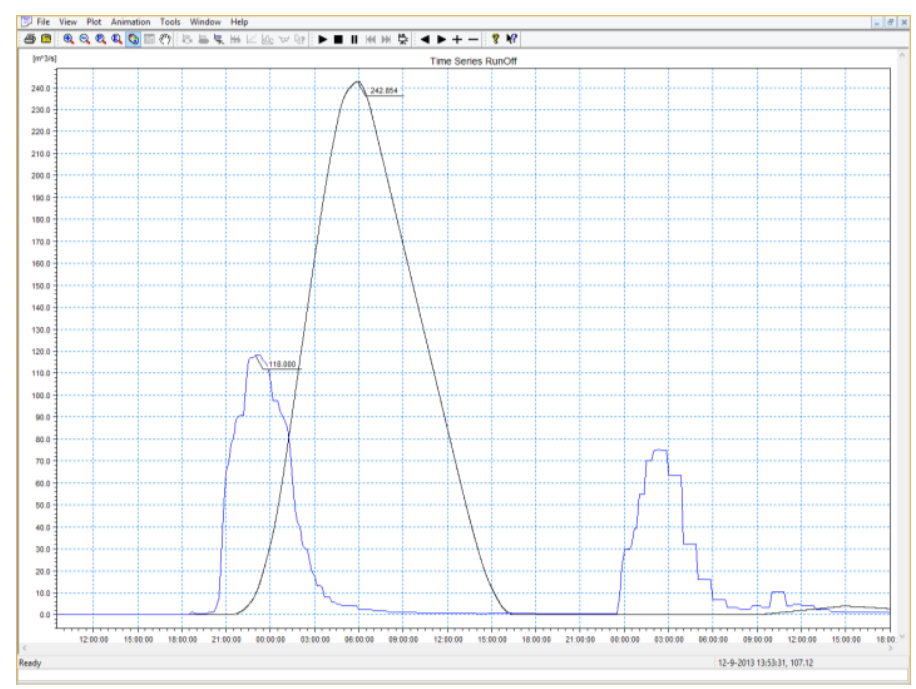

Fig.4. Discharges measured at AHSS Cudalbi and discharges simulated with Mike 11-UHM (AHSS precipitation, $\mathrm{AMC}=1$, area adjustment factor $=1$, the simulation time step $=10$ minutes $)$ Discharges simulated with Mike 11-UHM Discharges measured at AHSS Cudalbi

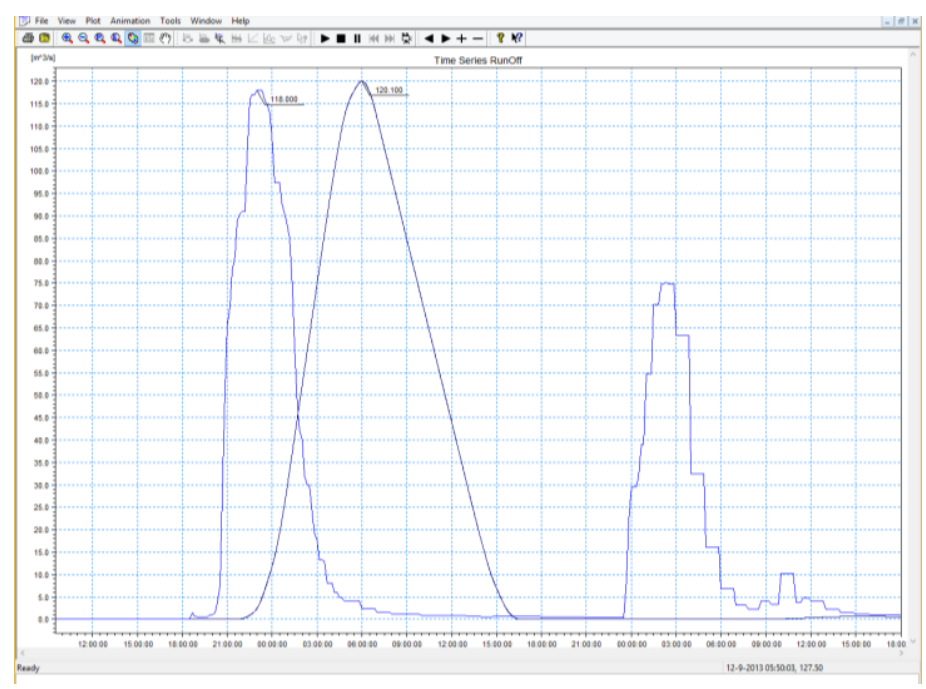

Fig.5. Discharges measured at AHSS Cudalbi and discharges simulated with Mike 11-UHM (AHSS precipitation, $\mathrm{AMC}=1$, area adjustment factor $=0.71$, the simulation time step $=10$ minutes $)$

- Discharges simulated with Mike 11-UHM

Discharges measured at AHSS Cudalbi 
The comparison between measured and simulated discharges leads to the conclusion that it is possible that some of the precipitation may have occurred in the upper catchment and were not recorded by AHSS Cudalbi, but in fact contributed to the formation of the other two peaks of the surface runoff that were not captured by the simulated hydrograph.

1.4. Mike 11-UHM simulations performed with the use of radar precipitation

Radar rainfall values were generated by ROFFG (Romanian Flash Flood Guidance) software system in ArcGIS module for determining the area affected by flash floods. ROFFG system is designed to provide information about the potential for flash flood of small catchments throughout Romania.

From the data processed by the system ROFFG we have used the product Merged Map - Average Precipitation accumulated in an hour, based on estimates of radar rainfall corrected by rainfall recorded at the automated stations.

For simulations using radar rainfall we have use the value $l$ for the area adjustment factor parameter, because this kind of input data characterize the catchment with high accuracy and the input file describe the distribution of precipitation closely to the actual distribution.

Radar rainfall radar with hourly frequency are shown in Figure 6.



Fig.6. Radar precipitations recorded between $11^{\text {th }}$ and $15^{\text {th }}$ of September 2013 
In the Simulation Result tab we used a 10 minutes time step for the initial stage of the simulation.

Figure 7 presents a comparison between the hydrograph of the discharges measured at AHSS Cudalbi between $11^{\text {th }}$ and $13^{\text {th }}$ of September 2013 and the hydrograph of discharges simulated with Mike 11- Unitary Hydrograph Method, in terms of value 1 for $A M C$ parameter and value 1 for area adjustment factor.

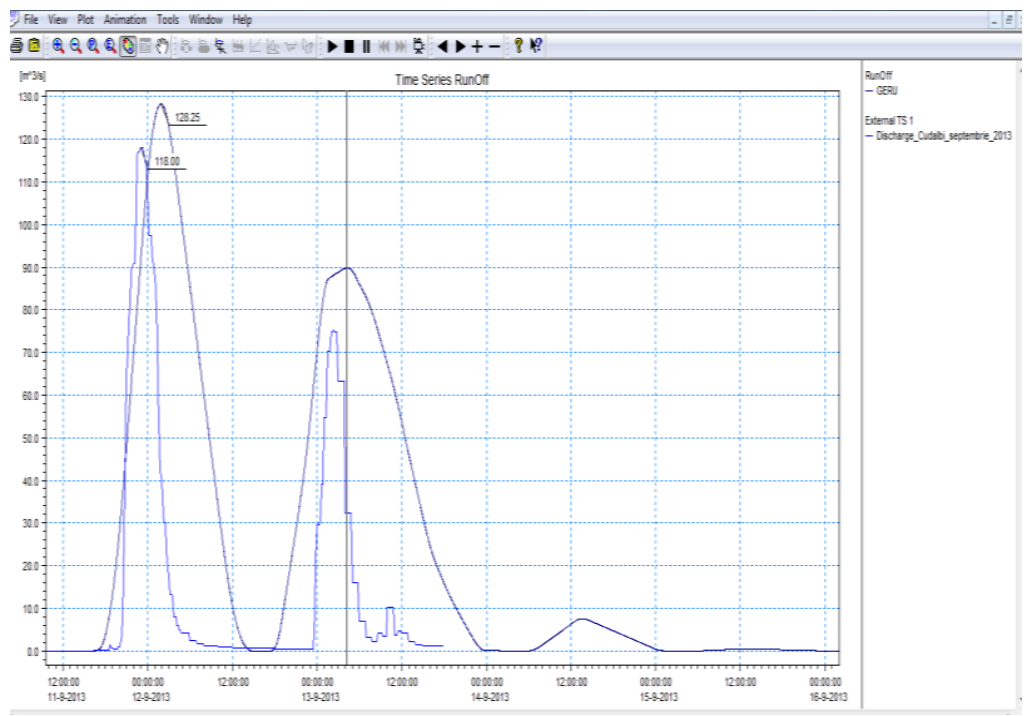

Fig.7. Discharges measured at AHSS Cudalbi and discharges simulated with Mike 11$\mathrm{UHM}$ (radar precipitation, $\mathrm{AMC}=1$, area adjustment factor $=1$, the simulation time step $=10$ minutes)

Discharges simulated with Mike 11-UHM

Discharges measured at AHSS Cudalbi

It is found that the first peak of the simulated discharge was $128.25 \mathrm{~m}^{3} / \mathrm{s}\left(12^{\text {th }}\right.$ of September $201305^{00}$ ), compared to the first peak of the measured discharge of $118.00 \mathrm{~m}^{3} / \mathrm{s}\left(11^{\text {th }}\right.$ of September $\left.201323^{00}\right)$, so the peak value is increased by $8.7 \%$ and appears to show 6 hours later than the measured peak.

The second peak of the simulated discharge was $89.82 \mathrm{~m}^{3} / \mathrm{s}\left(12^{\text {th }}\right.$ of September $201307^{16}$ ), compared to the second peak of the measured discharge of $75.30 \mathrm{~m}^{3} / \mathrm{s}$ $\left(13^{\text {th }}\right.$ of September $\left.201302^{20}\right)$, so the value is increased by $19 \%$ and appears to show 5 hours later than the measured peak.

The third peak of the simulated discharge was $7.47 \mathrm{~m}^{3} / \mathrm{s}\left(14^{\text {th }}\right.$ of September $201316^{30}$ ), compared to the third peak of the measured discharge of $10.30 \mathrm{~m}^{3} / \mathrm{s}$ 
$\left(13^{\text {th }}\right.$ of September $\left.201310^{20}\right)$, so the value is diminished by $27 \%$ and appears to show 30 hours later than the measured peak.

The simulated hydrograph captures the shape of the measured hydrograph with all three discharge peaks with different phase and amplitude errors. The first peak of the hydrograph is captured with acceptable error amplitude and phase.

An hourly time step was chosen for the next stage of the simulation, in order to match the time step of the recorded precipitation used as input data. The simulated discharge hydrograph obtained from the hourly simulation step is shown in figure 8, in comparison with the measured discharge hydrograph at AHSS Cudalbi.



Fig. 8. Discharges measured at AHSS Cudalbi and discharges simulated with Mike 11$\mathrm{UHM}$ (radar precipitation, $\mathrm{AMC}=1$, area adjustment factor $=1$, the simulation time $\mathrm{step}=1$ hour)

Discharges simulated with Mike 11-UHM Discharges measured at AHSS Cudalbi

It is found that the first peak of the simulated discharge was $120.72 \mathrm{~m}^{3} / \mathrm{s}$ (on $12^{\text {th }}$ of September $201302^{00}$ ), compared to the first peak of the measured discharge of $118.00 \mathrm{~m}^{3} / \mathrm{s}$ ( on $11^{\text {th }}$ of September $201323^{00}$ ), so the peak value is increased by $2.3 \%$ and appears to show 3 hours later than the measured peak.

The second peak of the simulated discharge was $85.57 \mathrm{~m}^{3} / \mathrm{s}$ (on $13^{\text {th }}$ of September $201305^{00}$ ), compared to the second peak of the measured discharge of 
$75.30 \mathrm{~m}^{3} / \mathrm{s}$ ( on $13^{\text {th }}$ of September $201302^{20}$ ), so the value is increased by $13.7 \%$ and appears to show 2.5 hours later than the measured peak.

The third peak of the simulated discharge was $7.04 \mathrm{~m}^{3} / \mathrm{s}$ (on $14^{\text {th }}$ of September $201313^{00}$ ), compared to the third peak of the measured discharge of $10.30 \mathrm{~m}^{3} / \mathrm{s}$ (on $13^{\text {th }}$ of September $201310^{20}$ ), so the value is diminished by $31 \%$ and appears to show 26.5 hours later than the measured peak.

The comparison between the results obtained with 10 minutes time step and hourly time step highlights that the amplitude errors are smaller when the model uses for simulation the same time step for data input and results. However, phase errors remain at the same value, offset from the actual moments of the maximum discharges measured at AHSS Cudalbi.

\section{Conclusions}

This paper analyzes the flood that occurred in the upper catchment of the river Geru between $11^{\text {th }}$ and $13^{\text {th }}$ of September and the simulation results obtained with the use of MIKE 11 - Unitary Hydrograph Method. Precipitation measured by AHSS Cudalbi and radar precipitation were used as input data.

Different time steps for the simulation results were used, in order to analyze the importance of accuracy of the input data on the simulation results and the direct influence of setting the time steps in achieving a close match of the simulated discharge hydrograph with the measured discharge hydrograph.

It appears that the hydrological modeling that used radar precipitation as data input, leads to a discharge hydrograph with low amplitude and phase errors, compared to the measured discharge hydrograph.

The model can be used in the future to reproduce the floods in the analyzed catchment and to study the influence of physical and geographical characteristics of hillslopes.

The results obtained by hydrological modeling can be used as input in hydraulic modeling. Hydraulic modeling and the drawing of flood maps are performed in order to predict the development of a high risk flood event, obtain the potentially flooded areas, the water depth in certain locations on the analyzed river sector.

\section{References}

Alexandrescu (cas. Chevereșan), M.(2010), Teză de doctorat - Gestiunea cantitativă a resurselor de apă în bazinul hidrografic Ialomița, Universitatea Tehnică de Construcții Bucureşti - Facultatea de Hidrotehnică

Apostol, A., (2011), Teză de doctorat - Modelarea scurgerii lichide și solide în bazine hidrografice cu activități agrosilvice, aplicații în prognoza hidrologică, Universitatea Tehnică de Construcții Bucureşti - Facultatea de Hidrotehnică 
Bîrsan, M.V., (2010), Teză de doctorat - Modelarea proceselor fizice de tip precipitaţiescurgere pentru prognoza în timp real a viiturilor, Universitatea din Bucureşti Facultatea de Fizica - Școala Doctorala

Crăciun, I., Giurma, C.-R., (2014), Hidrologie specială - Aplicații, Ed. Performantica, Iaşi

Ioniță, F., (2011, Teză de doctorat - Formarea viiturilor și delimitarea zonelor inundabile in bazine hidrografice, Universitatea Tehnică de Cosntrucții București - Facultatea de Hidrotehnică

Kirkby, M., (1971) , Hillslope process - response models based on the continuity equation. In Slopes form and processes Instit. British Geography Specifications Pub. No. 3: $15-30$

Natural Resources Conservation Services USDA, (1986), National Engineering Handbook-Part 630 Hydrology, chapter 7-12

Natural Resources Conservation Services USDA, (1986), Urban Hydrology for Small Watersheds-Technical Release 55

*** (2003), MIKE 11 - A modelling system for rivers and channels - User guide - DHI Agern Alle 5, DK-2970 Horsholm, Denmark

*** (2003), MIKE $11-$ A modelling system for rivers and channels - Short introduction tutorial - DHI- Agern Alle 5, DK-2970 Horsholm, Denmark

*** (2006), MIKE 11 Users Manual - DHI water and environment, DK-2970 Horsholm, Denmark DHI

*** (2011), MIKE 11 Reference Manual - DHI water and environment, DK-2970 Horsholm, Denmark DHI

Administraţia Bazinală Prut - Bârlad, (2014), Raport anual de sinteză privind activitatea de urmărirea comportării construcțiilor din patrimoniul Administrației Bazinale de Apă Prut-Bârlad în anul 2013 